\title{
Towards the Development of an Inter-cultural Scale to Measure Trust in Automation
}

\author{
Shih-Yi Chien ${ }^{1}$, Zhaleh Semnani-Azad ${ }^{2}$, Michael Lewis ${ }^{1}$, and Katia Sycara ${ }^{3}$ \\ ${ }^{1}$ School of Information Sciences, University of Pittsburgh, Pittsburgh, PA, 15260 USA \\ ${ }^{2}$ Department of Psychology, University of Waterloo, Waterloo, Ontario, N2L3G1 Canada \\ ${ }^{3}$ Robotics Institute, Carnegie Mellon University, Pittsburgh, PA 15213 USA \\ shc56@pitt.edu, mlasis.pitt.edu, \\ zsemnani@uwaterloo.ca, katia@cs.cmu.edu
}

\begin{abstract}
Trust is conceived as an attitude leading to intentions resulting in user actions involving automation. It is generally believed that trust is dynamic and that a user's prior experience with automation affects future behavior indirectly through causing changes in trust. Additionally, individual differences and cultural factors have been frequently cited as the contributors to influencing trust beliefs about using and monitoring automation. The presented research focuses on modeling human's trust when interacting with automated systems across cultures. The initial trust assessment instrument, comprising 110 items along with 2 perceptions (general vs. specific use of automation), has been empirically validated. Detailed results comparing items and dimensionality with our new pooled measure will be presented.
\end{abstract}

Keywords: Trust, Automation, Culture, Technology Adoption, Human Computer Interaction (HCI), Human Factors.

\section{Introduction}

Human interaction with automation is a complex process. Humans may fail to use automation when it is advantageous (disuse), fail to monitor it properly when in use (misuse), or accept its recommendations and actions when inappropriate [1]. Trust (in automation) has most often been studied indirectly through its purported influence on behavior often without any direct cognitive measure. Studies have shown [2-4] that trust towards automation affects reliance (i.e., people tend to rely on automation they trust and not use automation they do not trust) and can be consistently measured.

While the reliability of the automation has a major influence on the operator's decision to trust and use automation, internal (e.g., personality) and external (e.g., cultural norms) factors can also significantly influence the level of trust [5]. Different contexts within trust have lead to definitions of trust as an attitude, an intention, or a behavior [6-8]. A widely accepted definition of trust is lacking, however, it is generally agreed the trust is best conceptualized as a multidimensional psychological attitude involving beliefs and expectations about the trustee's trustworthiness derived from experience and interactions with the trustee [9]. 
In both the interpersonal trust literature and automation trust literature [10], trust has been said to have both cognitive and affective features. In the interpersonal literature, trust is also seen involving affective processes, since trust development requires seeing others as personally motivated by care and concern to protect the trustor's interests [11]. In the automation literature, cognitive (rather than affective) processes may play a dominant role in the determination of trustworthiness, i.e., the extent to which automation is expected to do the task that it was designed to do [12]. In the trust in automation literature, it has been argued that trust is best conceptualized as an attitude [13] and a relatively well accepted definition of trust is: "an attitude which includes the belief that the collaborator will perform as expected, and can, within the limits of the designer's intentions, be relied on to achieve the design goals" [14]. The conceptualization of trust as an attitude having both cognitive and relational aspects is especially relevant to our research on how culture may modulate trust construal and dimensions of trustworthiness. It has been hypothesized, and supported by various studies, that individual differences [5], [13], [15], [16] and culture [17] affect the trust behavior of people with respect to automation. For example, it has been shown [18] via replication of Hofstede's [19] cultural dimensions for a very large-scale sample of pilots, that even in such a highly specialized and regulated profession, national culture still exerts a meaningful influence on attitude and behavior over and above the occupational context. In fact, there would be no need for an intervening variable such as trust if outside factors did not exert a substantial influence over trust decisions.

While models of trust, Lee and See [13], invariably acknowledge the multiplicity of these influences. However, the majority of research on trust in automation has focused on the relation between automation reliability and operator usage often without measuring the intervening variable, trust. The utility of introducing an intervening variable between automation performance and operator usage lies in the ability to make more precise or accurate predictions with the intervening variable than without it. This requires that trust in automation be influenced by factors in addition to automation reliability/performance. There are two general limitations to the current literature. First, most of the work on cultural influences on trust has been done in the context of interpersonal trust [20], [21]. Second, most of the very limited work studying culture and trust in automation has been abstract and suggestive, without empirical validation. With respect to trust in automation across cultures, two of the very few studies [22], [23] examined the effects of culture-sensitive interactions on the willingness of adopting an information technology. However, the studies focused mainly on online behaviors and failed to contribute a uni-dimensional instrument to examine the wide variety of contexts in applying automated systems. Despite the plethora of research in trust and culture in inter-personal relations, there is a dearth of studies investigating the effect of culture on trust in automation. To address these issues, the overall objective of our research is to develop a fundamental understanding of general principles and factors pertaining to trust in automation, and how trust mediates reliance on automation across cultures. 


\section{Instrument Development}

Attempts to measure trust in automation such as Muir's questionnaire [12] or the many questionnaires created for individual studies have not (in general) benefited from the same rigor in development and validation that has characterized measures of interpersonal trust. The Empirically Derived (ED) scale developed by Jian et al. [24] is a notable exception that has been subjected to a validation study [25] and used elsewhere [26]. Madsen and Gregor's Human-Computer Trust (HCT) instrument [8] demonstrated construct validity and high reliability within their validation sample and has subsequently been used to assess trust in automation in air traffic control simulations [27]. The SHAPE Automation Trust Index (SATI) [28] is the most pragmatically oriented of these formally developed measures, with items refined for usability and construct validity in focus groups of air traffic controllers. All three scales have benefited from empirical study and systematic development yet each has its flaws. ED addresses trust in automation in the abstract without reference to an actual system. The HCT stopped short of confirmatory factor analysis leaving its true dimensionality uncertain. The SATI neglected psychometric tests of construct and content validity.

The initial steps involve developing an instrument capable of reliably assessing trust in automation. Developing this begins with the pool of items from the ED, HCT, and SATI and augmented items from 5 existing studies intended to increase the reliability of the discovered dimensions. The initial instrument comprises 110 items falling into a variety of constructs, as shown in Appendix A.

\subsection{Pilot Test - General vs. Specific Automation}

Despite the variety of automated systems (e.g., smartphone apps vs. industrial robots), the trusting beliefs would be influenced significantly regarding the purpose of the automation. To develop an instrument capable of reliably assessing trust in automation, the initial step began with identifying the purpose of the aforementioned items to general or specific uses of automation. 45 participants were recruited from the University of Pittsburgh community for categorizing the characteristics of the selected items. The participants first read the following description:

"Please respond to the following statements about your trust in automation. By automation, we mean any technology or service that you have used before, including apps, devices, functions, or systems. Based on your experience, use the following scale to rate the extent to which you agree(5) or disagree(1) with the statements below. Note, no wrong responses to any of the statements, the most critical is to record your own true opinion on each item. If you think the provided instruction is not sufficient to answer the question, please rate insufficient information."

The instrument was measured using a 5-point Likert scale (from strongly disagree to strongly agree), however, an item may be rated as insufficient if the participants believed the item/question has to refer to a targeted system. Once an item was rated as 
insufficient more than once, the item was categorized as specific use. Additionally, after reviewing the general items, 7 items with high neutral rates (more than $1 / 3$ of the participants) were also classified as specific purpose. Among the 110 items, 70 items fell into the general cluster, whereas 40 items were in the specific group.

\subsection{Scale Refinement}

An initial test has been conducted to refine our trust instrument. A pool of questions, consisting of 110 items along with 2 perceptions (general vs. specific use of automation) was adopted. A total of 65 paid participants was recruited on Amazon Mechanical Turk (MTurk). The instrument was measured using a 5-point Likert scale, asking respondents to detail their trust beliefs in automated systems. The instrument comprised two parts, general and specific uses of automation. Automated navigation devices (e.g., GPS) were introduced as the specific automation (table 1); in the general automation, instead of pointing out targeted systems, the participants can name any experienced automated tools.

Table 1. Descriptions of general and specific automation

\begin{tabular}{|c|l|}
\hline $\begin{array}{c}\text { General } \\
\text { automation }\end{array}$ & $\begin{array}{l}\text { By "Automation" we mean any technology or service that takes } \\
\text { actions automatically and that you have used, including apps, devic- } \\
\text { es, functions, or systems. }\end{array}$ \\
\hline $\begin{array}{c}\text { Specific } \\
\text { automation }\end{array}$ & $\begin{array}{l}\text { By "Automation" we focus mainly on GPS Navigation System in- } \\
\text { cluding all types of navigation devices that you have used, such as } \\
\text { an automotive navigation system (e.g., Garmin) or Smartphone } \\
\text { navigation apps (e.g., Google map). }\end{array}$ \\
\hline
\end{tabular}

Data gathered in the test was used to refine our scale by rewording or identifying problematic items. Exploratory factor analysis (EFA) was used to determine the dimensionality of the data and loading of items in order to refine the instrument. A principal components factor analysis with varimax rotation was performed to examine the number of factors produced. A five-factor model was returned that explained $52.4 \%$ of the variance in general automation (details not shown here due to space constraints); whereas $70.2 \%$ of the variance of the specific automation was represented by a five-factor model (Appendix B). The internal consistency and reliability were examined (table 2, 3). If the resulting Cronbach's alpha is lower than 0.7, the factor will be eliminated (as factor 4 in table 3). Through the aforementioned analysis, 59 items (40 general and 19 specific automation) that met the validity and reliability criteria were retrieved to refine the instrument. The finding factors greatly involved in three clusters: performance expectancy, process transparency, and purpose influence. Performance expectancy is defined as an individual's belief that applying an automation will help the individual to enhance job performance; process transparency involves the encountered difficulties based on the perceived transparency of an automaton (i.e., how an automation functions); purpose influence relates to a person's knowledge of what the automation is supposed to do (i.e., initial trust or faith in automation). 
Table 2. Reliability Statistics in General Automation

\begin{tabular}{|c|c|c|c|}
\hline $\begin{array}{c}\text { General } \\
\text { Auto }\end{array}$ & Cronbach's Alpha & $\begin{array}{c}\text { Cronbach's Alpha Based on } \\
\text { Standardized Items }\end{array}$ & Num of Items \\
\hline Factor 1 & .922 & .922 & 13 \\
\hline Factor 2 & .867 & .871 & 6 \\
\hline Factor 3 & .892 & .890 & 9 \\
\hline Factor 4 & .863 & .870 & 7 \\
\hline Factor 5 & .718 & .732 & 5 \\
\hline
\end{tabular}

Table 3. Reliability Statistics in Specific Automation

\begin{tabular}{|c|c|c|c|}
\hline $\begin{array}{c}\text { Specific } \\
\text { Auto }\end{array}$ & Cronbach's Alpha & $\begin{array}{c}\text { Cronbach's Alpha Based on } \\
\text { Standardized Items }\end{array}$ & Num of Items \\
\hline Factor 1 & .943 & .944 & 10 \\
\hline Factor 2 & .836 & .835 & 3 \\
\hline Factor 3 & .818 & .821 & 3 \\
\hline Factor 4 & .626 & .628 & 2 \\
\hline Factor 5 & .760 & .797 & 3 \\
\hline
\end{tabular}

\section{Conclusion}

Trust has been frequently cited as a contributor to decisions about using and monitoring automation [13]. In this paper, we report initial steps toward developing an instrument capable of reliably assessing trust in automation across cultures. We began with the pool of 53 items from the ED, HCT, and SATI and augmented them with new items intended to increase the reliability of discovering dimensions. A total of 110 items (70 general and 40 specific) were empirically validate via MTurk. Through the validity and reliability tests, 59 items (40 general and 19 specific) were selected.

To further examine the external validity of the instrument, another round of data collection will be conducted to cross-validate the instrument. We will additionally collect data on Hofstede's [19] cultural dimensions to provide a fuller picture of cultural differences and their relation to the trust scale being developed. We expect the research will have a significant impact on the design, implementation and evaluation of automation to make it more trustworthy in general and in aiding the appropriate trust calibration for optimized reliance across cultures.

Acknowledgements. This research has been sponsored by AFOSR FA9550-13-1-0129.

\section{References}

1. Lyons, J.B., Stokes, C.K.: Human-Human Reliance in the Context of Automation. Human Factors The Journal of the Human Factors and Ergonomics Society (2012)

2. Lee, J., Moray, N.: Trust, control strategies and allocation of function in human-machine systems. Ergonomics 35(10), 1243-1270 (1992) 
3. Muir, B., Moray, N.: Trust in automation. Part II. Experimental studies of trust and human intervention in a process control simulation. Ergonomics (1996)

4. Lewandowsky, S., Mundy, M., Tan, G.P.: The dynamics of trust: comparing humans to automation. Journal of Experimental Psychology. Applied (2000)

5. Masalonis, A.J., Parasuraman, R.: Effects of training operators on situation-specific automation reliability 2, 1595-1599 (2003)

6. Mayer, R.C., Davis, J.H., Schoorman, F.D.: An Integrative Model of Organizational Trust. Academy of Management Review (1995)

7. Moray, N., Inagaki, T., Itoh, M.: Adaptive Automation, Trust, and Self-Confidence in Fault Management of Time-Critical Tasks. Experimental Psychology: Applieed (2000)

8. Madsen, M., Gregor, S.: Measuring human-computer trust. In: 11th Australasian Conference on Information Systems, vol. 53, pp. 6-8 (2000)

9. Jones, G.R., George, J.M.: The Experience and Evolution of Trust: Implications for Cooperation and Teamwork. The Academy of Management Review (1998)

10. Adams, B., Webb, R.: Trust in small military teams. In: 7th International Command and Control Technology Symposium (2002)

11. Lewis, J., Weigert, A.: Trust as a social reality. Social Forces (1985)

12. Muir, B.: Trust in automation: Part I. Theoretical issues in the study of trust and human intervention in automated systems. Ergonomics 37(11), 1905-1922 (1994)

13. Lee, J., See, K.: Trust in automation: designing for appropriate reliance. Human Factors 46(1), 50-80 (2004)

14. Moray, N., Inagaki, T.: Laboratory studies of trust between humans and machines in automated systems. Transactions of the Institute of Measurement and Control (1999)

15. Singh, I.L., Molloy, R., Parasuraman, R.: Individual differences in monitoring failures of automation. Journal of General Psychology 120(3), 357-373 (1993)

16. Merritt, S., Ilgen, D.: Not All Trust Is Created Equal: Dispositional and History-Based Trust in Human-Automation Interactions. Human Factors: The Journal of the Human Factors and Ergonomics Society 50(2), 194-210 (2008)

17. Karvonen, K.: Designing trust for a universal audience: A multicultural study on the formation of trust in the internet in the nordic countries. In: HCI (2001)

18. Merritt: Culture in the Cockpit: Do Hofstede's Dimensions Replicate? Journal of CrossCultural Psychology 31(3), 283-301 (2000)

19. Hofstede: Cultures And Organizations - Software of the Mind. Development (1991)

20. Gunia, B.C., Brett, J.M., Nandkeolyar, A.K., Kamdar, D.: Paying a price: culture, trust, and negotiation consequences. The Journal of Applied Psychology (2011)

21. Fulmer, C.A., Gelfand, M.J.: Dynamic Trust Processes: Trust Dissolution and Restoration, pp. 1-32 (2010)

22. Kim, D.: Cognition-Based Versus Affect-Based Trust Determinants in E-Commerce: Cross-Cultural Comparison Study. In: ICIS, pp. 741-753 (2005)

23. Lee, I., Choi, B., Kim, J., Hong, S.: Culture-technology fit: effects of cultural characteristics on the post-adoption beliefs of mobile internet users. International Journal of Electronic 11(4), 11-51 (2007)

24. Jian, J., Bisantz, A., Drury, C.: Foundations for an empirically determined scale of trust in automated systems. International Journal of Cognitive (2000)

25. Spain, R.D., Bustamante, E.A., Bliss, J.P.: Towards an Empirically Developed Scale for System Trust: Take Two. Proceedings of the Human Factors and Ergonomics Society Annual Meeting 52(19), 1335-1339 (2008) 
26. Master, R., Jiang, X., Khasawneh, M.T., Bowling, S.R., Grimes, L., Gramopadhye, A.K., Melloy, B.J.: Measurement of trust over time in hybrid inspection systems. Human Factors and Ergonomics in Manufacturing 15(2), 177-196 (2005)

27. Luz, M.: Validation of a Trust survey on example of MTCD in real time simulation with Irish controllers (2009)

28. Organisation, E., The, F.O.R., Of, S., Navigation, A.I.R., Air, E., Management, T.: Guidelines for Trust in Future ATM Systems: Measures Guidelines for Trust in Future ATM Systems: Measures Guidelines for Trust in Future ATM Systems: Measures (2003)

29. Im, I., Hong, S., Kang, M.S.: An international comparison of technology adoption. Information \& Management 48(1), 1-8 (2011)

30. Venkatesh, V., Morris, M., Davis, G., Davis, F.: User acceptance of information technology: Toward a unified view. MIS Quarterly 27(3), 425-478 (2003)

31. Hwang, Y., Lee, K.C.: Investigating the moderating role of uncertainty avoidance cultural values on multidimensional online trust. Information \& Management (2012)

32. Srite, M., Karahanna, E.: The role of espoused national cultural values in technology acceptance. MIS Quarterly 30(3), 679-704 (2006)

33. Limayem, M., Khalifa, M., Frini, A.: What makes consumers buy from Internet? A longitudinal study of online shopping. Systems, Man and Cybernetics (2000)

34. Mcknight, D., Carter, M.: Trust in a specific technology: An investigation of its components and measures. ACM Transactions on Management Information Systems (2011)

35. Halpert, A., Horvath, A., Preston, F., Somerville, K., Semnani-azad, Z.: Technological Adoptiveness Scale (TAS): Internal Properties and Construct Validity (2008) 
Appendix A. Initial trust instruments: root constructs and definitions

\begin{tabular}{|c|c|c|}
\hline $\begin{array}{c}\text { International Comparison of } \\
\text { Technology Adoption }\end{array}$ & Constructs & Definitions* \\
\hline \multirow{4}{*}{$\begin{array}{l}\text { ICTA (International Comparison of } \\
\text { Technology Adoption [29]) compared } \\
\text { the use intention of information tech- } \\
\text { nologies across different cultural con- } \\
\text { texts. The UTAUT instrument [30] } \\
\text { was selected to examine the cultural } \\
\text { effects. The survey comprised } 14 \text { items } \\
\text { within } 5 \text { factors, in which } 11 \text { items } / 4 \\
\text { factors were chosen for our test. } \\
\text { *All the definitions are cited from } \\
{[30] \text {. }}\end{array}$} & $\begin{array}{l}\text { Performance } \\
\text { expectancy }\end{array}$ & $\begin{array}{l}\text { "An individual believes } \\
\text { that using the system will } \\
\text { help him or her to attain } \\
\text { gains in job performance." }\end{array}$ \\
\hline & Effort expectancy & $\begin{array}{l}\text { "The degree of ease asso- } \\
\text { ciated with the use of the } \\
\text { system." }\end{array}$ \\
\hline & Social influence & $\begin{array}{l}\text { "The degree to which an } \\
\text { individual perceives that } \\
\text { important others believe } \\
\text { she should use the new } \\
\text { system." }\end{array}$ \\
\hline & $\begin{array}{l}\text { Facilitating } \\
\text { conditions }\end{array}$ & $\begin{array}{l}\text { "The degree to which an } \\
\text { individual believes that an } \\
\text { organizational and tech- } \\
\text { nical infrastructure exists } \\
\text { to support use of the sys- } \\
\text { tem." }\end{array}$ \\
\hline Culture-Technology Fit & Constructs & Definitions* \\
\hline \multirow{2}{*}{$\begin{array}{l}\text { CTF (Culture-Technology Fit [23]) } \\
\text { investigates the trustworthy relation- } \\
\text { ship between cultural contexts and } \\
\text { post-adoption beliefs in the use of the } \\
\text { mobile Internet. CTF includes } 30 \\
\text { items/ } 10 \text { factors ( } 3 \text { items for each). The } \\
\text { cultural profiles (uncertainty avoidance } \\
\text { and individualism) were selected for } \\
\text { our test. } \\
\text { *All the definitions are cited from } \\
{[23] \text {. }}\end{array}$} & $\begin{array}{l}\text { Uncertainty } \\
\text { Avoidance }\end{array}$ & $\begin{array}{l}\text { "The extent to which the } \\
\text { members of a culture feel } \\
\text { threatened by uncertain or } \\
\text { unknown situations." }\end{array}$ \\
\hline & Individualism & $\begin{array}{l}\text { "Individualism represents } \\
\text { a preference for a loosely } \\
\text { knit social framework in } \\
\text { which people are expected } \\
\text { to take care of themselves } \\
\text { and to look after their own } \\
\text { interests." }\end{array}$ \\
\hline Online Trust Beliefs & Constructs & Definitions \\
\hline $\begin{array}{l}\text { OTB (Online Trust Beliefs [31]) ex- } \\
\text { amined the moderating role of uncer- } \\
\text { tainty avoidance in online trust beliefs } \\
\text { between subjective norms and the } \\
\text { integrity \& ability dimensions. OTB } \\
\text { adopted } 16 \text { items within } 6 \text { factors from }\end{array}$ & $\begin{array}{l}\text { Uncertainty } \\
\text { Avoidance }\end{array}$ & $\begin{array}{l}\text { "Uncertainty avoidance is } \\
\text { the level of risk accepted } \\
\text { by the individual. This } \\
\text { dimension examines the } \\
\text { extent to which one feels } \\
\text { threatened by ambiguous }\end{array}$ \\
\hline
\end{tabular}




\begin{tabular}{|c|c|c|}
\hline \multirow{5}{*}{$\begin{array}{l}\text { [32] and [33], in which } 12 \text { items } / 5 \\
\text { constructs were selected for inclusion } \\
\text { in our test. }\end{array}$} & & situations [32]." \\
\hline & Subjective Norms & $\begin{array}{l}\text { "Social factors that are } \\
\text { likely to influence the } \\
\text { online shopping inten- } \\
\text { tions/behavior [33]." }\end{array}$ \\
\hline & Benevolence & $\begin{array}{l}\text { "The belief that the trusted } \\
\text { party, while hoping to } \\
\text { make a profit, wants to do } \\
\text { good to the customer } \\
\text { [31]." }\end{array}$ \\
\hline & Integrity & $\begin{array}{l}\text { "A trusted party adheres to } \\
\text { accepted rules of conduct, } \\
\text { such as honesty and keep- } \\
\text { ing promises [31]." }\end{array}$ \\
\hline & Intention & $\begin{array}{l}\text { The behavioral intent of a } \\
\text { buyer to precede the act of } \\
\text { purchasing [31]. }\end{array}$ \\
\hline Trust in Specific Technology & Constructs & Definitions* \\
\hline \multirow{6}{*}{$\begin{array}{l}\text { TIST (Trust in Specific Technology } \\
\text { [34]) examines different kinds of trust } \\
\text { across contexts and technologies, from } \\
\text { specific (e.g., Excel or spreadsheet } \\
\text { products) to general uses in automated } \\
\text { tools. } \\
\text { The scale comprises } 26 \text { items within } 7 \\
\text { factors, in which } 19 \text { items } / 6 \text { constructs } \\
\text { are adapted to our test. } \\
\text { *All the definitions are cited from } \\
\text { [34]. }\end{array}$} & $\begin{array}{c}\text { Specific } \\
\text { Technology } \\
\text { Reliability } \\
\end{array}$ & $\begin{array}{l}\text { "The belief that the specif- } \\
\text { ic technology will consis- } \\
\text { tently operate properly." }\end{array}$ \\
\hline & $\begin{array}{l}\text { Specific } \\
\text { Technology } \\
\text { - Functionality }\end{array}$ & $\begin{array}{l}\text { "The belief that the specif- } \\
\text { ic technology has the } \\
\text { capability, functionality, } \\
\text { or features to do for one } \\
\text { what one needs to be } \\
\text { done." }\end{array}$ \\
\hline & $\begin{array}{l}\text { Situational } \\
\text { Normality } \\
\text { - Technology }\end{array}$ & $\begin{array}{l}\text { "One feels comfortable } \\
\text { when one uses the general } \\
\text { type of technology of } \\
\text { which a specific technolo- } \\
\text { gy may be an instance." }\end{array}$ \\
\hline & $\begin{array}{l}\text { Structural } \\
\text { Assurance } \\
\text { - Technology }\end{array}$ & $\begin{array}{l}\text { "One believes structural } \\
\text { conditions like guarantees, } \\
\text { contracts, support, or other } \\
\text { safeguards exist in the } \\
\text { general type of technology } \\
\text { that make success likely." }\end{array}$ \\
\hline & $\begin{array}{l}\text { Faith in General } \\
\text { Technology }\end{array}$ & $\begin{array}{l}\text { "One assumes technolo- } \\
\text { gies are usually consistent, } \\
\text { reliable, functional, and } \\
\text { provide the help needed." }\end{array}$ \\
\hline & $\begin{array}{l}\text { Trusting Stance } \\
\text { - General } \\
\text { Technology }\end{array}$ & $\begin{array}{l}\text { "One presumes that one } \\
\text { will achieve better out- } \\
\text { comes by assuming the } \\
\text { technology can be relied } \\
\text { on." }\end{array}$ \\
\hline
\end{tabular}




\begin{tabular}{|c|c|c|}
\hline Empirically Derived & Constructs & Definitions \\
\hline \multirow{2}{*}{$\begin{array}{l}\text { ED (Empirically Derived [24]) incor- } \\
\text { porates a three-phased experiment, } \\
\text { comprised a word elicitation study, a } \\
\text { questionnaire study, and a paired com- } \\
\text { parison study, was performed to empir- } \\
\text { ically develop a scale to measure trust } \\
\text { between people and automated sys- } \\
\text { tems. } 12 \text { items, falling into two factors } \\
\text { (trust \& distrust), are incorporated in } \\
\text { the instrument. All the items are se- } \\
\text { lected to our test. }\end{array}$} & Trust & $\begin{array}{l}\text { The trust factor comprises } \\
7 \text { main items: confidence, } \\
\text { security, integrity, depen- } \\
\text { dability, reliability, trust, } \\
\text { and familiarity. }\end{array}$ \\
\hline & Distrust & $\begin{array}{l}\text { The distrust factor com- } \\
\text { prises } 5 \text { main items: } \\
\text { deceptiveness, underhan- } \\
\text { dedness, suspiciousness, } \\
\text { wariness, and harm. }\end{array}$ \\
\hline Human-Computer Trust & Constructs & Definitions* \\
\hline \multirow{5}{*}{$\begin{array}{l}\text { HCT (Human-Computer Trust [8]) } \\
\text { scale is designed to examine trust in } \\
\text { intelligence systems (taxi dispatch } \\
\text { system was used in their study). HCT } \\
\text { instrument comprises } 25 \text { items ( } 5 \\
\text { constructs, each with } 5 \text { items to reflect } \\
\text { the concept). All the items are adapted } \\
\text { to our test. }\end{array}$} & $\begin{array}{l}\text { Perceived } \\
\text { Reliability }\end{array}$ & $\begin{array}{l}\text { "Reliability of the system, } \\
\text { in the usual sense of re- } \\
\text { peated, consistent func- } \\
\text { tioning." }\end{array}$ \\
\hline & $\begin{array}{c}\text { Perceived } \\
\text { Technical } \\
\text { Competence }\end{array}$ & $\begin{array}{l}\text { "A system is perceived to } \\
\text { perform tasks accurately } \\
\text { and correctly based on the } \\
\text { information that is input." }\end{array}$ \\
\hline & $\begin{array}{c}\text { Perceived } \\
\text { Understandability }\end{array}$ & $\begin{array}{l}\text { "A human supervisor or } \\
\text { observer can form a men- } \\
\text { tal model and predict } \\
\text { future system behavior." }\end{array}$ \\
\hline & Faith & $\begin{array}{l}\text { "A user has faith in the } \\
\text { future ability of the system } \\
\text { to perform even in situa- } \\
\text { tions in which it is un- } \\
\text { tried." }\end{array}$ \\
\hline & $\begin{array}{l}\text { Personal } \\
\text { Attachment }\end{array}$ & $\begin{array}{l}\text { "A user finds using a } \\
\text { system agreeable and it } \\
\text { suits her taste." }\end{array}$ \\
\hline SHAPE Trust Index & Constructs & Definitions* \\
\hline $\begin{array}{l}\text { SATI (SHAPE Automation Trust } \\
\text { Index [28]) measures human trust of } \\
\text { automated systems in controlling air } \\
\text { traffic management tasks. The scale } \\
\text { measures controller's trust twice, pre }\end{array}$ & Reliability & $\begin{array}{l}\text { "The extent to which you } \\
\text { can rely on the machine to } \\
\text { consistently support the } \\
\text { tasks." }\end{array}$ \\
\hline
\end{tabular}




\begin{tabular}{|c|c|c|}
\hline \multirow{6}{*}{$\begin{array}{l}\text { and post-adoption use, in order to } \\
\text { obtain human feedback and sensitively } \\
\text { examine the fluctuation in trust. The } \\
\text { first part comprises } 4 \text { questions and the } \\
\text { second part consists of } 8 \text { sections. } 16 \\
\text { items within } 7 \text { constructs, are chosen } \\
\text { for inclusion in the test. } \\
\text { *All the definitions are cited from } \\
\text { [28]. }\end{array}$} & Accuracy & $\begin{array}{l}\text { "Accuracy of machine in } \\
\text { supporting successful } \\
\text { completion of tasks." }\end{array}$ \\
\hline & Understanding & $\begin{array}{l}\text { "The extent to which the } \\
\text { machines' decision on } \\
\text { when and how to inter- } \\
\text { vene and support the task } \\
\text { requires assessment, } \\
\text { knowledge, and under- } \\
\text { standing of the task." }\end{array}$ \\
\hline & Faith & $\begin{array}{l}\text { "The extent to which you } \\
\text { believe that the machine } \\
\text { will be able to intervene } \\
\text { and support the tasks in } \\
\text { other system states in the } \\
\text { future." }\end{array}$ \\
\hline & Liking & $\begin{array}{l}\text { "The extent to which you } \\
\text { can anticipate and expect } \\
\text { the machine to support the } \\
\text { tasks." }\end{array}$ \\
\hline & Familiarity & $\begin{array}{l}\text { "The extent to which you } \\
\text { have confidence in the } \\
\text { machines' decision on } \\
\text { when and how to inter- } \\
\text { vene and support the } \\
\text { task." }\end{array}$ \\
\hline & Robustness & $\begin{array}{l}\text { "The extent to which you } \\
\text { can count on the machine } \\
\text { to provide the appropriate } \\
\text { support to the tasks." }\end{array}$ \\
\hline Technological Adoptiveness Scale & Constructs & Definitions \\
\hline $\begin{array}{l}\text { TAS (Technological Adoptiveness } \\
\text { Scale [35]) is a } 12 \text { item measure that } \\
\text { examines a person's relative openness } \\
\text { to adopting and using new technology. } \\
9 \text { items were chosen for inclusion in } \\
\text { our test. }\end{array}$ & $\begin{array}{c}\text { General } \\
\text { Technology } \\
\text { - Adoptiveness }\end{array}$ & $\begin{array}{l}\text { The attitude of openness } \\
\text { in adopting any technolo- } \\
\text { gy that has been released } \\
\text { recently and is unfamiliar } \\
\text { to a user. }\end{array}$ \\
\hline
\end{tabular}


Appendix B. EFA (exploratory factor analysis) results: specific use of automation (21 items/5 factors). The model of specific items with a threshold value 0.4 , in order to eliminate the noise. Note. (r): recode values.

\begin{tabular}{|c|c|c|c|c|c|}
\hline \multicolumn{6}{|c|}{ Rotated Component Matrix $^{a}$} \\
\hline & \multicolumn{5}{|c|}{ Component } \\
\hline & 1 & 2 & 3 & 4 & 5 \\
\hline I can rely on automation to ensure my performance. & .830 & & & & \\
\hline Automation improves my performance. & .750 & & & & \\
\hline It is easy to follow what automation does. & .725 & & & & \\
\hline $\begin{array}{l}\text { Automation makes use of all the knowledge and } \\
\text { information available to produce its solution to the } \\
\text { problem. }\end{array}$ & .708 & & & & \\
\hline $\begin{array}{l}\text { The advice automation produces is as good as that } \\
\text { which a highly competent person could produce. }\end{array}$ & .696 & & & & \\
\hline $\begin{array}{l}\text { Automation correctly uses the information I pro- } \\
\text { vided. }\end{array}$ & .680 & & & & \\
\hline I am confident in automation. & .646 & & & & \\
\hline $\begin{array}{l}\text { Automation always provides the advice I require to } \\
\text { make my decision. }\end{array}$ & .627 & & & & \\
\hline Using automation increases my productivity. & .606 & & & & \\
\hline $\begin{array}{l}\text { Using automation enables me to accomplish tasks } \\
\text { more quickly. }\end{array}$ & .542 & & & & \\
\hline $\begin{array}{l}\text { Automation has sound knowledge about the type } \\
\text { of problem for which it is intended. }\end{array}$ & & .726 & & & \\
\hline Automation is friendly to use. & & .702 & & & \\
\hline $\begin{array}{l}\text { Automation uses appropriate methods to reach } \\
\text { decisions. }\end{array}$ & & .618 & & & \\
\hline $\begin{array}{l}\text { Automation may result in unpredictable situations. } \\
\text { (r) }\end{array}$ & & & .838 & & \\
\hline Automation does not fail me. & & & .783 & & \\
\hline I believe automation could be faulted. (r) & & & .761 & & \\
\hline I understand how automation works. & & & & .827 & \\
\hline I am wary of automation. (r) & & & & .611 & \\
\hline I am suspicious of automation's intent. (r) & & & & & .842 \\
\hline Automation is deceptive. (r) & & & & & .758 \\
\hline $\begin{array}{l}\text { Automation behaves in an underhanded manner. } \\
\text { (r) }\end{array}$ & & & & & .750 \\
\hline
\end{tabular}

